\title{
11 Maps, migration, melancholia
}

\author{
Pradeep Jeganathan
}

On 18 June 2012, I thought I had found something long lost. In the face of it, it was something I had never had as part of my material lived world: a dwelling of my ancestors, the abode of my great-grandfather, Saravanamuttu, built at the turn of the 20th century, after he had retired as a medical practitioner. The house, which he called "Saravana Villa", was in Kattudai, Manipay, a subdivision of a subdivision - certainly in those days a village, if you like - in the peninsula of Jaffna at the northern tip of Sri Lanka, then British Ceylon.

But when I grew up, in the southern capital of Colombo, in the 1970s and 1980s, Jaffna and this place of dwelling had long been left behind. Of course, the ownership, by complicated rules of inheritance, had passed to a relative, but my mother, Saravamuttu's granddaughter, Vijaya-Lakshmi, had never gotten around to taking me there, preferring other, perhaps more "educational", sites as destinations for our family trips during school vacations.

By the time I had come of age and proceeded overseas for my education, in 1983, Sri Lanka was seeing the beginnings of a civil war that would stretch on, with pulsating, grotesque intensity for some 30 years. Jaffna was now a place too far, too unsafe, for a nostalgic visit - even though, of course, many lived there, migrated, and even returned in those difficult days. But their investments were different.

In June 2012, I had visited Jaffna at the invitation of Thamotharampillai Shanaathanan, one of Sri Lanka's most serious artists and a scholar, for a short series of lectures in the Department of Art History and Fine Arts at the University of Jaffna. After that visit and teaching - as I lodged with Sana for a while - as he is a very dear friend - I asked him if we could try to find ancestral home. He agreed, and after much asking and looking - of course, Google Maps couldn't know where we were going - I had my mother on aural mobile at my ear, however - we found it. It is I, who found it in the end, I like to think, because I saw the name of the place, etched in my mind from many childhood stories, on the gate post (Figure 11.1). ${ }^{1}$

I gave a little whoop of joy - "We found it! We found it" - to Sana and my mother on the phone, and then we walked in the garden, where Sana pointed out to me the distinctive double-column architecture, and my mother, through aural guidance, another remarkable feature, the sophisticated - for its time - private outdoor bathing facility that had been built for her mother, my grandmother, when 


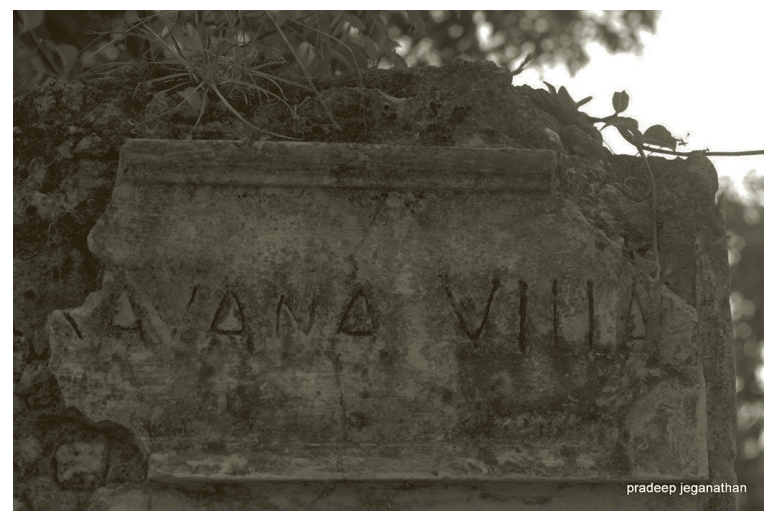

Figure 11.1 Ruined Gatepost, Saravana Villa, Kaddudai, Manipai, Jaffna.

she had joined the household as the young bride of Karthigesu, Saravanamuttu's second son.

The house was in shambles, still owned by a distant cousin in Australia but occupied by a refugee family from the Vanni whom neither I nor anyone in my family knew, or knew of, but I was overjoyed to find what was left, what I had left behind, and had thought lost in that space of longing, attachment and memory, somewhere between Roland Barthes's the "has been", and "no longer" (1981: 76-77).

But when we went back to his place, I could see Sana was sad. Crestfallen. When we talked, he told me he grieved to see what had become of the beautiful house and even more so to see what had become of the finely wrought sculptures in the family temple behind the house accessed by walking across picturesque paddy fields. This is a temple where the direct male descendants of Saravanamuttu fund, in absentia, an annual ritual to this day. "I can tell what kind of people they were, and we have lost them now", said Sana.

Shanaathanan's statement is a dense one, and much of the work I attempt in this chapter is its unpacking at many levels, but I first note what I think may be already clear. An affective conceptualization of migrations, of differing paths and horizons, given varying intensities of investments in what is left behind, and what is travelled to is at the heart of his statement. Indeed, it is the loss, of people, things, and places that imbue him with sadness. This painting (see Figure 11.2), ${ }^{2}$ part of an early moment in his oeuvre, is telling in the juxtaposition of the sharp claws of the prosthetic plough that lacerates the head of the grieving man, even as his teeth stream down, seemingly self-extracted.

Let me begin this unpacking, with a very brief historical portrait of the Jaffna Tamil Vellalar community, through the 17 th century to the 1950 s. The Jaffna Tamil Vellalar, it can be argued, were a community created, in part, by 17 thand 18th-century Dutch colonial rule as part of its strategic promotion of the extremely lucrative tobacco cultivation for export to the "Malabar" coast. The dominance of the Vellalar - which, in the contemporary anthropological sense, can be seen as a dominant cultivator caste - the classic account of which is found 


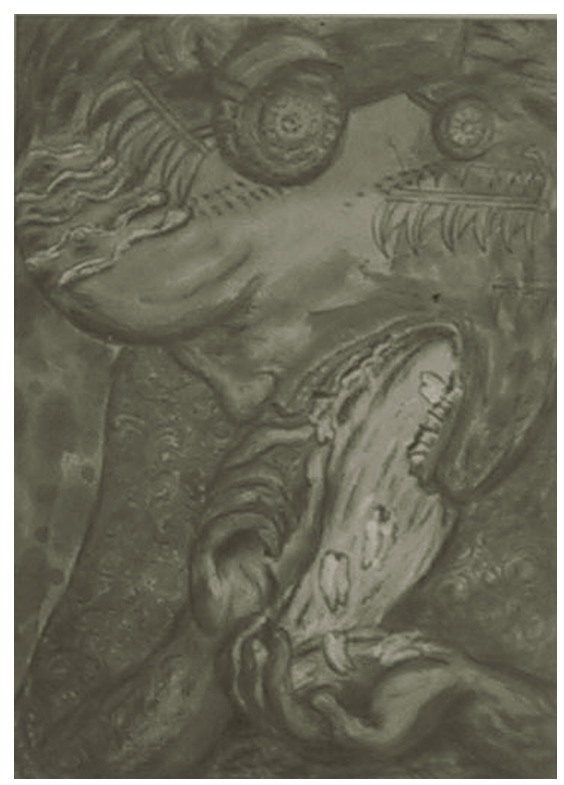

Figure 11.2 "All Is Falling" (2000). Mixed media on canvas. Thamodarampillai Sanaathanan, Artist.

in M. N. Srinivas (1959) - was supported and enhanced by the Dutch who produced a now-familiar effect, by codifying "customary law," which then, in turn, regularized private property, remade caste hierarchy, and compelled migratory labour from South India to live under a regime of caste slavery while working on the tobacco fields (Arasaratnam 1986).

The Vellalar grew rich, and this community was already well monetized because of a historical accident during British rule in the very early part of the 19th century, when a dense network of American missionary schools, including the first boarding school for girls in Asia, led to the creation of an educated elite unmatched in its density anywhere else in Sri Lanka, in Sinhala or Tamil regions - ready for colonial employment, by the early 20th century (de Alwis 1997). In fact, the products of these schools - and this is about a particular, very limited form of colonial education - migrated as far afield as British Malaya to serve in the clerical and railway services before returning to recapitalize the densely populated peninsula with mansions - many of which may be viewed and studied to this day in their ruined state. Most are larger than "Saravana Villa", I must add, even though the double-column architecture does date to this period.

By the mid-1920s, British Ceylon was booming, the surplus value created by another labour migration - to the central hills, very far from the northern tip, and the port of Colombo, then the third-busiest port in the empire - allowing for larger-scale, state-sector employment and a demand for professional services. The Jaffna Tamil Vellalar flowed into those opportunities, not only in the clerical services and railways but also in the more prestigious civil service and the 
learned professions, such as medicine, law and engineering, which took them in a great migration all over the island but also to the Sinhala south. But this migration, was not at that time, a final movement. Jaffna remained home - old houses were maintained, and families had a dual existence, living both in the South and North simultaneously, with the North receiving net capital transfers. So not only were the Jaffna Tamil Vellalar co-equals with Sinhala elites in the upper tiers of Ceylonese polity (Arasaratnam 1994; Sriskandarajah 2005), property prices in the peninsula, in the estimates of one anthropologist, were possibly in excess of the cost of comparable property in rural districts of England (Pfaffenberger 1990).

One can see at once that when attempting even this brief sketch of people and place how central the concept of migration becomes. Conceptually, I think it fruitful to think the terms of region and migration, as imbricated to such an extent that I would like to run the two words together, as in "(mig)region". In so doing, I want to keep in mind the themes I began with, the horizons of departure and return, from the region and the subjects' intensities of investments in what is lost and what is found. I return to this theme later in this chapter.

Region, I conceptualize, as "ruled", "lived", and "mapped". While perhaps arbitrary and certainly incomplete, it is my sense that looking in from these angles may allow "region" to be both an always already problematized and yet categorically available in an analytical account. These are, I want to suggest, angles of view, not water-tight compartments; in fact, they must be seen in a conjectural articulation, with attention being paid to the centre of gravity each may imply. Region, then, may be seen as an articulation of these angles of view, always historically and socioculturally constituted and creatively imagined, in the sense of virtual and actual. Of these tripartite axes, I would take a moment to underline the mapped, as process, which, of course, is implicated in life, the navigation or lived movement in variously mapped worlds, its making and marking, which in a different register is one of governmentality and rule, but even more, as object or artefact, as in a map that scales to the human, as in a map in an atlas. That said, I will return to these conceptual musings before I end this chapter. I now move back to the story of Tamil migrations.

If the place of the Jaffna Tamil Vellalar, in the administrative service and the learned professions, and in between, was made in succession by two colonial states, the contestation of that place came with post-colonial democracy. In the 1950s, just as in India, when linguistic nationalism came to the fore, S. W. R. D. Bandaranaike, the Sinhala leader who founded a political dynasty, took up language as his campaign slogan, promising "Sinhala Only", in 24 hours. Since English had been the official language up until then, this policy, which began to be implemented in 1956, created two competing linguistic nationalisms. So the dominance of the Jaffna Tamil Vellalar was folded into a hegemony which worked on the idea of Tamil-speaking people, erasing caste and class dominations that continued to exist.

As a consequence of this contest, given that violence began to emerge soon after - anti-Tamil riots in 1956 and then again in 1958, culminating in the great punctuation point in the modern history of Sri Lanka, the massive pogrom cum 
riot of July 1983 - two maps of Sri Lanka began to emerge. This led to a protracted civil war, a long time of violence ended by the Sri Lankan armed forces in May 2009, the second major punctuation point in the modern history of Sri Lanka (Jeganathan 2017).

In essence, these punctuation points, which mark the "beginning" and "end" of a long civil war, also produce two competing maps. Superimposed on one another, almost, one was a Sinhala nationalist map, which claimed all of Lanka for the Sinhala and the Buddhists, and the other, a Tamil Nationalist map, which claimed the northern and eastern portion of the island for itself. This developed over time, and migrant bodies were crucial to its becoming; on one hand, there were Sinhala settlers whose movement to the North Central Province was enabled by successive states and, on the other, in the face of anti-Tamil violence in the south, Tamils who were moved back to Jaffna, at first temporarily, for their own safety. When these displaced persons would return to the south, they would again, face attack, perhaps a generation later, encouraging a more permanent movement back. By the 1980s, the sedimentations of violence had begun to consolidate these two maps; through the 1990s, and then up to 2009, a long war, with periodic ceasefires, produced further sedimentations.

I explicate the density of these divisive maps, with recourse to the lives and deaths of three imaginative figures from Sri Lankan literature and cinematography who exemplify these punctuation points.

First, let me consider the liveability of the Sinhala south, for the Tamil who is the subject of violence. In Ernest MacIntyre's play Rasanayagam's Last Riot, set in July 1983, Rasanayagam, a southern Tamil who is neither a separatist nor a militant and who speaks both English and Sinhala well enough to "pass", has faced riot after riot, which he has escaped, taking shelter in the homes of Sinhala friends or, more dangerously, passing through "checkpoints" of Sinhala men bent on perpetration, by pronouncing a Baldiya (bucket) the Sinhala way rather than the Tamil way, Valdiya. He continues this performance, these tactics - which I have called "tactics of anticipation" elsewhere (Jeganathan 2000) - throughout the play, negotiating the line between the serious and the parodic until finally, as it were, he refuses in one profound moment to do it any more - refuses to perform his Tamilness as Sinhalaness - and is then killed by a "mob" that has surrounded him.

Rasanayagam chooses not to treat 1983 as just another riot that might be assimilated into memory, as a "has-been", but his is not the refrain of "never again" of the survivor who lives on. If his death is an underlining of the "no longer", it creates through a density of a null point, a new ordinary on the lived map, which tells of the impossibility of life. Vast numbers of southern Tamils migrated back to the north after the riots of 1983, many of whom joined armed movements, and in the embrace of the most grotesque and fearsome of these, the Liberation Tigers of Tamil Eelam (LTTE), returned to the streets on which Rasanayagam walked, as suicide bombers, who, unlike he, took other lives as they died, even as the Sri Lankan armed forces began attacks, with great force, in what Tamil nationalists considered their homeland.

Selvi, is another such figure I take from Prasanna Vithanage's film With You, Without You (2012). ${ }^{3}$ Here, we find Selvi, a young Tamil girl, out of place in the 
central hills of Sri Lanka, in between the Jaffna Tamil north and southern south, among hill-country Tamils who are ethnically distinct from the Jaffna Tamils. Her brothers have been killed in the civil war, and she has seen terrible atrocities. Selvi attempts to be a good wife to a Sinhala pawn-broker who works hard building his business and is gentle with her until she realizes that he was a former soldier who has covered up a militarized rape in the past. She can no longer be with him, or with herself, and kills herself.

Here, in this instance, we have the liveability of the Sinhala-Tamil marriage made impossible by prior atrocity. It is important, however, to note that there are two "migregions" here, both from where the protagonists, both Sinhala Army husband and Tamil wife, have come, the first from employment and the second from dwelling: the Jaffna Tamil north. Inhabitation there has been made impossible for both, but for the Tamil woman, even the intermediate zone of the Tamil hill country is unliveable despite the love of a Sinhala man.

The third imaginative figure I wish to introduce is Dheepan, ${ }^{4}$ the protagonist of the eponymous film of 2015, which depicts a militant, defeated by war, who, together with two other war refugees - a grown woman and a young girl child constitutes a contingent "family" so they can apply for asylum in France. Even though Dheepan works hard at his new job as a cleaner, drug-related "gang" battles in Paris, as well as the long hand of the LTTE, reinserts him in violence. While he survives to live on, in a remarkable climactic scene, we see Dheepan act out an episode of repressed violent experience, in a Parisian neighbourhood.

The battle of the Tamil homeland is embedded in the migrant.

This homeland, now thought of as much larger than the peninsula of Jaffna, is a region, a migration, that may be understood in the senses of the lived, ruled, and mapped that I delineated previously and to which I am now returning as promised - the map on a human scale, the map as in an atlas. The map of Eelam, then, is a point of reference for my analysis. It has, as a reproducible artefact, an enormous life, which I cannot do justice to here; I can only sketch some of its contours.

First, we must note the enormous Tamil migrations out of Sri Lanka, catalysed by violence. Such migrants, of course, carry complex maps with them, the map of Tamil Eelam, as artefact is but one. Fascinatingly, for analysis, this period of migration is also simultaneous with the extraordinary rise of distributed computing - or, if you like, the internet - and then, by the 1990s, the availability of "webspace", as a graphical screen to migrants. When I first began to address this puzzle of the then uncertain emergence of the map of Tamil Eelam in webspace, in 1997, what I noticed was the production of a kind of non-indexical space, which was then, quite unusual (Jeganathan 1998).

For example, the webspace of the University of Chicago, where I was at the time, www.uchicago.edu, invoked a sense of place or, in other words, worked hard to index or reference its webspace. On the other hand, the webspace invoked by www.fedex.com, the courier company, sort of hides its own location by indexing the possibility of the movement of a package from place to place; www.eelam.com, then a very new site, did neither. The space it invoked was non-indexical - while a map was drawn, it had little inside it, it did not even refer to the places of Tamil Eelam, that were, at a minimum, cartographically available. 
In a sense, there was no "there there"; the there was here. Other migrant Tamil nationalist websites, at the time, were rich with details of place but yet did not invoke so centrally the bare map.

Of course, webspace has changed much since - far too much to be waded into here - but as far as indexicality goes, there are both Google Maps on the go and Google Street View. Such deep referentiality may even make the very idea of a certain kind of frozen web map obsolete, one may think. Interactivity in its infinitude is on us. And, yes, in current maps of the areas of Tamil Eelam, such detailed interactivity is available. For example, a US Tamil diaspora group (a PAC, or political action committee, in terms of US politics) attempts to map the militarization of the north of Sri Lanka, with state-aided Sinhala settlements and army camps marked. Here, that the map of Eelam's bounds is gone; and the map is simply that of Sri Lanka, and the details provided that of Sinhala military colonization.

\section{A map that has been: love and loss}

Yet the bare, idealized imaginative map persists, as an iconic artefact, on posters, placards, cards, or even mugs. Thought dually, through Partha Chatterjee's (1993) argument with Benedict Anderson, which insists on the material creativity of the national imagination, read together with Lacan's understanding of the screen, which operates a split between the eye and the gaze, with the gaze being drawn to the stain, in a turning back which is an avoidance of "as seeing oneself see oneself" as in a mirror ([1964] 1978: 83), or as if we read Freud's (1916) understanding of Mona Lisa's smile, as the stain of Da Vinci's gaze, in Lacan's terms, the flattened, idealized iconicity of the portable map of Eelam, may be decipherable as an object that never was and never will be, one always already lost as it is loved. This is best seen in the map of Tamil Eelam, which appears as a tear. ${ }^{5}$

I owe to Sigmund Freud's classic 1917 (1957) essay "Mourning and Melancholia" the idea that psychic investments in objects - and I see objects here, as both ideal and material - can be worked through. In Freud, there are two sharply juxtaposed ways of working through investments. What he calls "normal affect of mourning", is seen as a working through an investment, so that the attachment to the lost object is finally severed ([1917] 1957: 267). This is contrasted with melancholia where cathartic energies turn inwards from that lost object, forming a narcissistic identification that can itself be ambivalent: raging and loving, hating and desiring, euphoric and abjecting (Ibid). An identification that can "change around into mania" (Ibid: 253). In this view, mourning is transformative, productive, psychic work, that lets go of the object, while melancholia is work that becomes its own object.

In thinking of ways to blur this sharp distinction made by Freud, I have found helpful a concise intervention made by Jennifer Radden (2002), who has pointed out that melancholy and melancholia are terms that are indeed quite different, both in a socio-historical and conceptual sense. Radden reminds us that melancholy was a state that could be moved in and out of, through and between; it was eminently Elizabethan and would be a better descriptor of Freud's only 
example in his text, Hamlet. Melancholia is rarely used today in clinical practice; it has been folded into the completely normalizing concept of "depression". Depression, in the way the term is used today, of course, lies quite outside that context. In fact, if one were to return to Foucault with Radden, one finds his half chapter "Mania and Melancholia" in Madness and Civilization (1988) most instructive on this point. My point is not to reinforce a sharp distinction between the terms melancholy and melancholia but, rather, to use Radden's work to question Freud's own distinction between mourning and melancholia. This is not a quibble for me as I am concerned with thinking melancholia simultaneously with melancholy so that I can conceptualize the work of melancholia, as both psychic and social, as ongoing, and perhaps even as productive.

I should underline, that in attempting to think of melancholia as work, I am not attempting to configure it as the work of recovery or getting beyond loss, which would be but a return to mourning. It is rather the kind of work, which after Veena Das's formulation I will call "inhabitation" as in the work of "[inhabiting] ... a world made strange by the desolating experience of ... loss" (1997: 67). In fact, it is Judith Butler (1997) who, in a characteristically insistent recursive reading of Freud's "Mourning and Melancholia", shows that Freud is not quite true to the conditions of possibility of his own terms; that the temporal logic of his terms leads to their own undoing so that the ego that turns back, inward, and may not be said to securely pre-exist the lost object; that as such, the distinction between "normal affect of mourning" and melancholia itself is rendered suspect. And even though the phrase "the work of melancholia" appears only three times in one passage in Freud's 1917 essay, almost as a wall of refusal that he cannot think beyond, it is Butler who elaborates the term as one that can map the bounds between the psychic and the social and that it can be work on one's self and work upon the world, at times of extraordinary loss.

It is instructive then to turn to Freud's reformulation of his ideas of 1917, in The Ego and Id ([1923] 1962). It is in this text that Freud suggests that he did not, in this earlier exploration of the question, appreciate the full significance of "melancholia", its frequency, and its typicality. In fact, we see that he has now moved to the view that such a loss and its refusal, in early childhood, through the ego's identification with the lost object, is fundamental to the "character of the ego" which he describes as "ally precipitate of abandoned object-cathexes" that "contains the history of those [previous lost] object-choices" ([1923] 1962: 29). However, in this essay, Freud is particularly concerned with such abandonment and identification which occurs in early childhood and then becomes central to the "Oedipal Complex" and the elaboration of the ego itself. Therefore, while this movement in his own thought, which is really a suggestion that the ego can be always already melancholic in his previous terms, is not taken up as such. It is Butler, who in a series of textual readings of Freud, suggests that one can read this abandonment and identification, if hetero-sexualization is not a given disposition, as producing gender "as a kind of melancholy" (1997: 102). Here I want to extend this argument that Butler has made in several ways over time, to think the "character of the ego", in Freud's terms, as being constantly made and remade in relation to the refusal of loss (melancholia) and the acceptance of loss 
(normal grief) as attachments and abandonments of ideal and material objects. This work, which, on one hand, is a suturing of melancholy and melancholia and, on the other, about investments in objects which have a irreducible sociality, is what I wish to call the "work of melancholia", not in the sense of Butler's melancholic agency but as a form of inhabitation that maps the horizons and intensities of a person's simultaneous psychic and social investments in what is loved and what is lost.

Let me return, to where I began, attempting to regain what I may not have been able to touch in the description of my return to that forever-lost place, "Saravana Villa", the dwelling of my ancestors. In doing so, I leave behind the idealized iconic map of Eelam with which I have been pre-occupied and, at the same, the dense indexicality of interactive webspace, however considered. Rather, now, I move to a consideration of the micro regions of the migrant, lived, ruled, and mapped in an entirely different way.

Thamotharampillai Shanaathanan, in a complex, creative and truly painstaking aesthetic project, which resulted in a very innovative graphical book The Incomplete Thombu (2011), which invokes Dutch rule and capitalization through the very idea of the land registry and the associated file, the land deed, replete with survey maps and architectural drawings, triangulates among those documents maps of rule, of a micro region, if you like - and displaced persons' maps of memory of lost dwellings, with his own aesthetic account of what lies in between. Here then is a very different set of maps of "migregion" that navigates the space and time between the "has been" and "no longer" in Barthes's terms, which I've been trying to juxtapose with Freud's distinction between the object of melancholia, which is never let go, and the object of mourning, which is released, given that both sets of distinctions are disturbed, as oppositions.

In an interview with his publisher, Shanaathanan puts it in his own words:

In The Incomplete Thompu book project my task was to respond to the diverse stories of completely different individuals. Hence the stories demanded a different kind of articulation; that reshaped my own drawing practice because the stories were not fully mine. This experience led me to make work in this form using a variety of styles. It is like telling my own story in other's voices that refer to different times, places and memories, using a collage of painting styles.

(Pereira, 2014)

In speaking of lending his hand to the voice of the other, of reshaping his own practice to capture what may be lost, that which we may never fully know, for we may not ever know what precisely is lost, Shanaathanan describes, in the most elegant terms, what his aesthetic practice demonstrates so viscerally: the many inflections of the work of melancholia, catalysed by displacement and loss, a kind of "migregion", if you can bear with my neologism.

If one thinks in terms of objects - taking the iconic map of Eelam and the densely indexical maps of dwellings in Shanaathanan's work - and juxtaposing them, leaving behind index and icon and the idea of representation that comes with it, and staying simply with the idea of investment in the objects, what shows 
up in stark relief, I would suggest, is the interior structure of the objects themselves in relation to these investments.

\section{Notes}

1 Photographed by Prof. Pradeep Jeganathan.

2 "All Is Falling" (2002). Thamotharampillai Shananthanan. Mixed media on canvas. (Dr.

Malathis de Alwis and Prof. Pradeep Jeganathan, private collection).

3 See https://www.imdb.com/title/tt2274706/.

4 See https://www.imdb.com/title/tt4082068/.

5 See http://www.salem-news.com/articles/november232011/tamil-eelam-rr.php.

\section{References}

Arasaratnam, Sinnappah. 1986. Merchants, Companies, and Commerce on the Coromandel Coast, 1650-1740. New Delhi: Oxford University Press.

Arasaratnam, Sinnappah. 1994. "Sri Lankas Tamils: under colonial rule," in C. Manogaran and B Pfaffenberger (eds), The Sri Lankan Tamils: Ethnicity and Identity. Boulder: Westview Press.

Barthes, Roland. 1981. Camera Lucida: Reflections on Photography. New York: Farrar, Straus and Giroux.

Butler, Judith. 1997. The Psychic Life of Power: Theories in Subjection. Stanford, CA: Stanford University Press.

Chatterjee, Partha. 1993. The Nation and its Fragments: Colonial and Postcolonial Histories. Princeton, NJ: Princeton University Press.

de Alwis, Malathi. 1997. "The Production and Embodiment of 'Respectability': Gendered Demeanours in Colonial Ceylon," in Michael Roberts (ed), Sri Lanka. Collective Identities Revisited, Vol. I. Colombo: Marga Institute Press.

Das, Veena. 1997. "Language and Body: Transactions in the Construction of Pain," in A. Kleinman, V. Das and M. Lock (eds), Social Suffering. Berkeley: University of California Press.

Foucault, Michel. 1988. Madness and Civilization: A History of Insanity in the Age of Reason. New York: Vintage.

Freud, Sigmund. 1916. Leonardo da Vinci: A Psychosexual Study of an Infantile Reminiscence. New York: Moffat, Yard \& Company.

Freud, Sigmund. [1917] 1957. "Mourning and Melancholia," in J. Strachy (trans. \& ed), The Standard Edition of the Complete Psychological Works of Sigmund Freud, Volume XIV (1914-1916): On the History of the Psycho-Analytic Movement, Papers on Metapsychology and Other Works. London: Hogarth Press.

Freud, Sigmund. [1923] 1962. "The Ego and the Id," in J. Strachy (trans. \& ed), The Standard Edition of the Complete Psychological Works of Sigmund Freud, Volume XIX (1923-1925). London: Hogarth Press.

Jeganathan, Pradeep. 1998. "eelam. com: Place, Nation, and Imagi-Nation in Cyberspace." Public Culture 10(3): 515-528.

Jeganathan, Pradeep. 2000. "On the anticipation of violence," in N. Long and A. Arce (eds), Anthropology, Development, and Modernities: Exploring Discourses, Countertendencies, and Violence. London: Routledge.

Jeganathan, Pradeep. 2017. "Justice After the Event: Sri Lanka's Civil Wars, Memory, Life and Reconciliation," in D. Mehta and R. Roy (eds), Violence and the Quest for Justice in South Asia. Delhi: Sage. 


\section{Pradeep Jeganathan}

Lacan, Jacques. [1964] 1978 "The Split Between the Eye and the Gaze," in The Four Fundamental Concepts of Psychoanalysis, trans. Alan Sheridan. New York: Norton.

Pereira, Sharmini. 2014. "T. Shanaathanan in Conversation with Sharmini Pereira." Groundviews: Journalism for Citizens, December 18. https://groundviews. org/2014/12/18/t-shanaathanan-in-conversation-with-sharmini-pereira/.

Pfaffenberger, Bryan. 1990. "The Political Construction of Defensive Nationalism: The 1968 Temple-Entry Crisis in Northern Sri Lanka.” The Journal of Asian Studies 49(1): 78-96.

Radden, Jennifer. 2002. The Nature of Melancholy: From Aristotle to Kristeva. Oxford: Oxford University Press.

Shanaathanan, Thamotherampillai. 2011. The Incomplete Thombu. London: Raking Leaves.

Srinivas, M. N. 1959. “The Dominant Caste in Rampura.” American Anthropologist 61(1): $1-16$.

Srinivas, M. N. 1987. The Dominant Caste and Other Essays. New Delhi: Oxford University Press.

Sriskandarajah, Dhananjayan. 2005. "Socio-Economic Inequality and Ethno-Political Conflict: Some Observations from Sri Lanka," Contemporary South Asia 14(3): 341-356. 